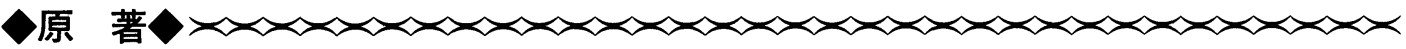

\title{
インビトロにおける非酵素的糖化現象の $\alpha_{2}$-プラスミン インヒビターにおよばす影響
}

$\begin{array}{llllll}\text { 山下 } & \text { 觔, 井誠 治, 井上かお り } \\ \text { 畠 田典子, 小林恵 美, 松岡 瑛 }\end{array}$

The Effects of Nonenzymatic Glycation on Human $\alpha_{2}$-Plasmin Inhibitor in Vitro

\author{
Tsutomu YAMASHITA, Seiji FUJII, Kaori INOUE, Noriko HATAKEDA, \\ Emi KOBAYASHI and Akira MATSUOKA
}

Key words : $\alpha_{2}$-Plasmin inhibitor, nonenzymatic glycation, lysine binding site I (LBS I), kringle binding site (KBS), active site binding site (ABS)

We studied the effects of nonenzymatic glycation on human $\alpha_{2}$-plasmin inhibitor $\left(\alpha_{2}-\mathrm{PI}\right)$ in vitro. Purified human $\alpha_{2}$-PI $(14.9 \mu \mathrm{M} / l)$ was incubated with glucose $(55.5 \mathrm{mM} / l)$ at $37^{\circ}$ $\mathrm{C}$ for 4 days. $\alpha_{2}$-PI was significantly glycated, and then the activity of glycated $\alpha_{2}$-PI decreased, while the levels of $\alpha_{2}$-PI antigen did not change. The amount of complexes which were formed between glycated $\alpha_{2}$-PI and plasmin $(5.0 \mathrm{U} / \mathrm{m} l)$ were less than that of control (control: $167.0 \sim 354.8 \mathrm{nM} / l$, glycated $\alpha_{2}-\mathrm{PI}: 25.2 \sim 105.4 \mathrm{nM} / l, \mathrm{p}<0.01$ ). $\alpha_{2}-\mathrm{PI}$ formed a complex of molecular weight in the region of $170 \mathrm{KD}$ with plasmin revealed by SDS-PAGE analysis. However, glycated $\alpha_{2}$-PI did not form a complex with plasmin. On crossed immunoelectrophoresis containing anti $\alpha_{2}$-PI antiserum in the second dimension, plasmin- $\alpha_{2}$-PI complex showed a major peak. On the contrary, glycated $\alpha_{2}$-PI demonstrated two major peaks including the slow moving one. The results are indicating that a glycated $\alpha_{2}$-PI is a form of non-binding for plasmin. Furthermore, when plasmin was added to the mixture of $\alpha_{2}$-PI and LBS I $(500 \mu \mathrm{g} / \mathrm{ml})$, the residual plasmin activity increased as the concentration of LBS I was increased. However, in case of glycated $\alpha_{2}-$ PI, LBS I had no effect on the residual plasmin activity. In addition, $\alpha_{2}$-PI was similarly glycated by incubating with glucose and LBS I.

From these observations, it is suggested that nonenzymatic glycation causes a chemical modification of KBS (Kringle Binding Site) and ABS (Active Binding Site) of $\alpha_{2}$-PI, and it is caused by poor formation of complex with plasmin and makes activity of $\alpha_{2}$-PI decrease.

兵庫医科大学病院中央臨床検査部〔 963 西宮市武庫川町 1-1〕; Department of Clinical Pathology and Clinical Laboratories Hyogo College of Medicine, 1-1 Mukogawa-cho Nishinomiya 663, Japan.

受付: 1994. 3. 25. 受理 : 1994.6.7. 


\section{緒 言}

血液中の種々タンパク質にグルコースが結合 する現象 (以下，糖化* と呼ぶ) は，非酵素的に 起こりこの非酵素的糖化現象により糖化された タンパク質の機能異常が報告されている ${ }^{1223)}$. 多くのタンパク質は主にその構成アミノ酸であ る Lysine 残基のフリーの グルコースが非酵素的に結合する4)5) 結果，その 構成に変化を受ける。凝固線溶系にかかわる 種々酵素，阻害物質において，この Lysine 残 基は非常に重要なアミノ酸である. 従って, 非 酵素的な糖化現象が凝固線溶因子に影響をおよ ぼす可能性が考えられる。プラスミンならびに $\alpha_{2}$ プラスミンインヒビター (以下 $\left.\alpha_{2}-\mathrm{PI}\right)$ にお いても Lysine 残基は非常に重要な機能を担う アミノ酸である．プラスミンの生理的阻害物質 である $\alpha_{2}$-PI は血液の線溶機構に対する特異 的な制御調節を有し，止血栓の維持およびその 溶解の調節に重要な役割を担っている67). その 先天的欠損症患者に出血傾向が認められること が知られている ${ }^{8)}$.しかし， $\alpha_{2}-\mathrm{PI}$ に対する非酵 素的糖化現象による影響についての報告はな い. 今回，われわれは非酵素的に糖化された $\alpha_{2}$ -PI のプラスミン阻害への影響を検索した。

\section{材料と方法}

$\alpha_{2}$-PI は純化ヒト $\alpha_{2}$-PI (ATHENS RESEACH ANDT ECHNOLOGY, INC.) $14.9 \mu \mathrm{M}$ を用いた。プラスミンはヒト Glu-プ ラスミノーゲン（SIGMA） $10 \mathrm{U} / \mathrm{m} l$ をウロキ ナーゼ（ヒト高分子量ウロキナーゼ，ミドリ十 字) $3,000 \mathrm{IU} / \mathrm{m} l$ にて活性化して用いた. プラス ミノーゲンリジンバインディングサイト I (LBS I) はヒトプラスミノーゲン由来リジンバ インディングサイト I (SIGMA) を用いた。

$\alpha_{2}$-PI 活性:健常人プール血漿を $100 \%$ とし てプラスミン阻害度を合成基質（S-2251， KABI）を用いて ${ }^{9}$ 測定した。

糖化蛋白量 : 糖化蛋白のもつケトアミンの還

*: 本論文で用いる糖化とは血漿中のタンパク質がグ ルコースと結合してアマドリ転位により安定なケ トアミンになることを指す.
元能を利用した塩化ニトロブルーテトラゾリウ ム塩の還元発色反応を用いた Johnson らの方 法10)にて定量した。糖化蛋白量は安定な糖化七 ト血清 (プレチマット,フルクトサミン, BMY) を標準物質とした。

$\alpha_{2}$-PI のプラスミン阻害に対する LBSI の影 響： $\alpha_{2}-\mathrm{PI}(14.9 \mu \mathrm{M})$ と合成基質 $(3 \mathrm{mM})$ の混 液に種々の濃度（0～ $500 \mu \mathrm{g} / \mathrm{m} l)$ の LBS I を 添加したのちプラスミン $(5 \mathrm{U} / \mathrm{m} l)$ を加えた直 後 $(0.5$ 秒後 $)$ から 10 秒間の吸光度の変化をと らえ比較した。測定は遠式方式汎用自動分析装 置 (COBAS FARA, BAXTER) を用いた。本 分析装置は反応系の種々条件が自由に設定可能 で，測光セル内の別べつの反応液を遠心方式で 混和することから反応開始直後の測定が可能で ある.

複合体形成過程の分析, 並びに形成量の定量 $\alpha_{2}$-PI $(14.9 \mu \mathrm{M})$ にプラスミン $(5 \mathrm{U} / \mathrm{m} l)$ を添 加し, 各種時間のインキュベーション後, 一定 量を取り出し，0.2 M 溶液の DFP（Diisopro pylfluorophosphate, SIGMA）にて反応を停止 させた試料について行った。

SDS ポリアクリルアミドゲル電気泳動 (SDS-PAGE) : Laemmli らの方法 ${ }^{11)} に$ 従い, 4〜20\%のグラジエントスラブゲル（第一化学 薬品）を用いて， $7 \mu l$ のサンプル量で $40 \mathrm{mA \text {, }}$ 1 時間泳動を行った. 銀染色は Sammone らの 方法 ${ }^{12)}$ に従って行った。分子量マーカーは高分 子量, 低分子量用電気泳動用キャリブレーショ ンキット（ファルマシア）を用い，同様に泳動 した。

二次元免疫電気泳動 (CIE) : $1 \%$ アガロース （和光純薬）を用いて第二相に $1 \%$ 抗ヒト $\alpha_{2}-\mathrm{PI}$ 抗血清（持田）を含ませてそれぞれ $2 \mathrm{~mA} / \mathrm{cm}$ で 3 時間泳動した。

プラスミン- $\alpha_{2}$-PI 複合体 (PIC) 量およびフ リー $\alpha_{2}$-PI 量: サンドイッチ EIA 法 ${ }^{13)}$ (PIC 「テイジン」， $\alpha_{2}$-PI「テイジン」帝人) を用いて 定量した。

\section{結＼cjkstart果}

1） $\alpha_{2}$-PI の非酵素的糖化

$\alpha_{2}$-PI $(14.9 \mu \mathrm{M} / l)$ 溶液にグルコースを 
Table 1 The effects upon $\alpha_{2}$-PI of nonenzymatic glycation. Purified human $\alpha_{2}$ -PI $(14.9 \mu \mathrm{M} / l)$ was incubated with glucose $(55.5 \mathrm{mM} / l)$ for 4 days at $37^{\circ} \mathrm{C}$ and activity, antigen and glycated protein was determined.

\begin{tabular}{lrcc}
\hline & Control $\alpha_{2}$ PI & $\begin{array}{c}\alpha_{2} \text { PI at glucose } \\
\text { concentration of } 55 \mathrm{mM} / l\end{array}$ \\
\hline Activity & $(\%)$ & $64.3 \pm 2.57$ & $9.1 \pm 2.6^{*}$ \\
Antigen & $(\%)$ & $77.7 \pm 5.8$ & $69.8 \pm 6.8$ \\
Glycated protein & $(\mu \mathrm{M} / l)$ & $3.9 \pm 0.52$ & $76.0 \pm 0.1^{*}$ \\
\hline
\end{tabular}

$*: \mathrm{P}<0.01$

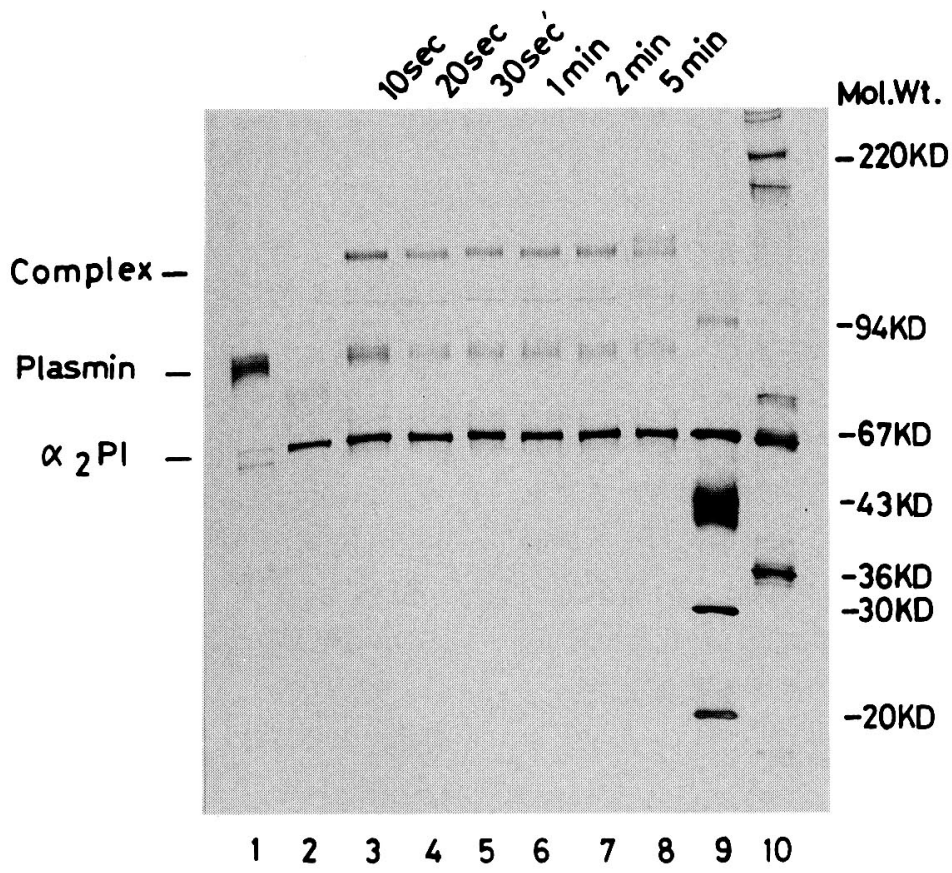

Fig. 1 Sodiumdodecyl sulfate gel electrophoretic analysis of the interaction of $\alpha_{2}$-PI and plasmin.

Control $\alpha_{2}$-PI was incubated with plasmin $(5 \mathrm{U} / \mathrm{m} l)$ for various times and the reaction was stopped by adding $0.2 \mathrm{M} \mathrm{DFP}$. Prior to electrophoretic analysis samples were added in $0.0625 \mathrm{M}$ tris- $\mathrm{HCl}$ (pH 6.8) containing, $2 \%$ sodium dodecyle sulfate, and $10 \%$ glycerol, $0.01 \%$ BPB. Samples of $7 \mu l$ were then applied to gel $(4 \sim 20 \%$ Polyacrylamide gradient gel, $84 \times 90 \times 1.0 \mathrm{~mm}$ ) and were run for 1 hour at $40 \mathrm{~mA}$. and silver staining was done. Lanel : Plasmin, Lane2 : $\boldsymbol{\alpha}_{2}-\mathrm{Pl}$, Lane3 $\sim 8$ : Plasmin $+\alpha_{2}-\mathrm{Pl}$, Lane9 $\sim 10$ : Molecular markers.

$55.5 \mathrm{mM} / l$ になるように添加して， 4 日間のイ ンキュベートを行った. その活性はインキュべ ーション前を $100 \%$ とした時, コントロールが $64.3 \pm 2.5 \%$ に対してグルコースとインキュべ ートした $\alpha_{2}$-PI は 9.1 $2.6 \%$ と著明な活性低 下が認められた．それに対して $\alpha_{2}-\mathrm{PI}$ 抗原量は
インキュベーション前を $100 \%$ とした時, コン トロールが $77.7 \pm 5.8 \%$ に対してグルコースと インキュベートした $\alpha_{2}-\mathrm{PI}$ は $69.8 \pm 6.8 \%$ と有 意な差を認めなかった。糖化タンパク量はコン トロールが $3.9 \pm 0.52 \mu \mathrm{M} / l$ に対してグルコー スとインキュベートした $\alpha_{2}-\mathrm{PI}$ は $7.60 \pm 0.13$ 


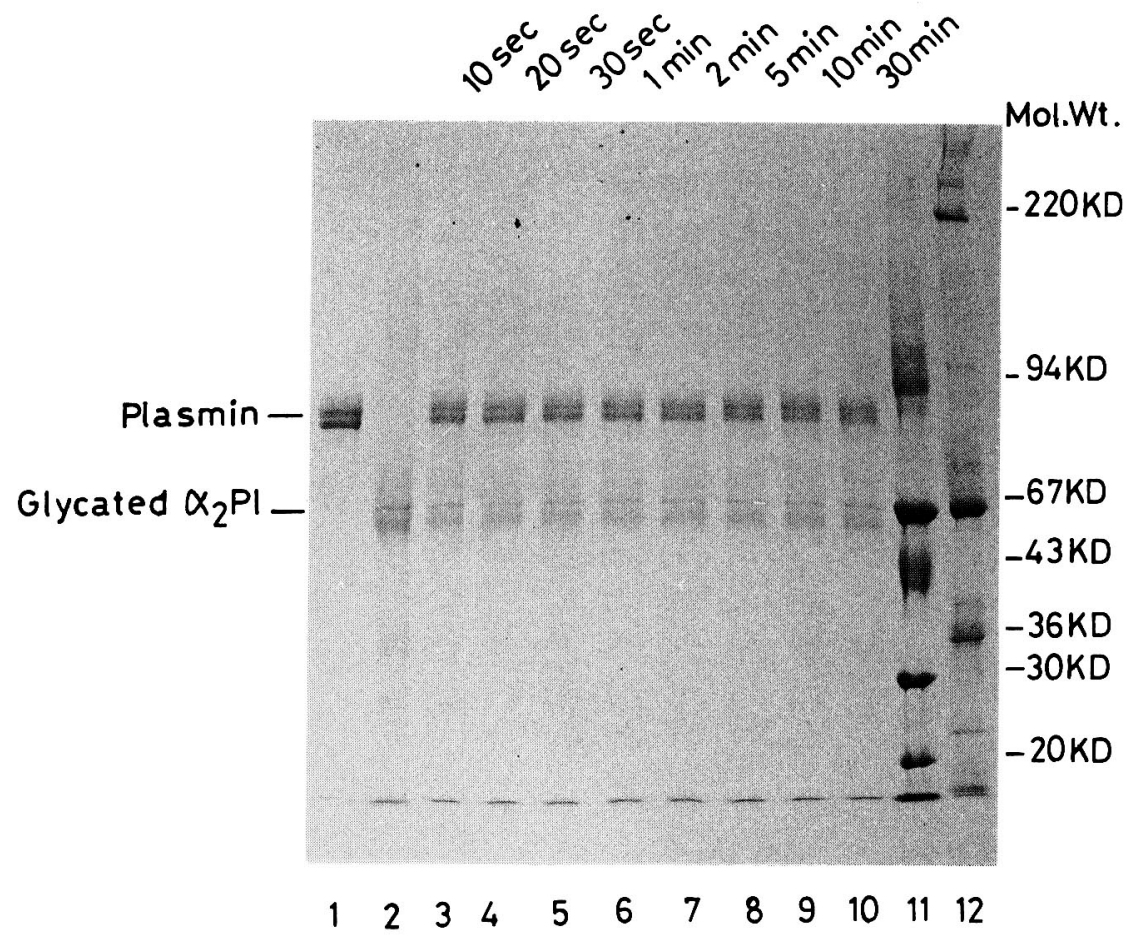

Fig. 2 Sodiumdodecyl sulfate gel electrophoretic analysis of the interaction of gycated $\alpha_{2}$-PI and plasmin.

glycated $\alpha_{2}$-PI was incubated with plasmin $(5 \mathrm{U} / \mathrm{m} l)$ for various times and the reaction was stopped by adding 0.2 M DFP. Electrophoretic analysis was done similarly. See Fig. 1 legend. Lanel : Plasmin, Lane2 : Glycated $\alpha_{2}-\mathrm{Pl}$, Lane3 10 : Plasmin + Glycated $\alpha_{2}-$ $\mathrm{Pl}$, Lane11 12: Molecular maskers

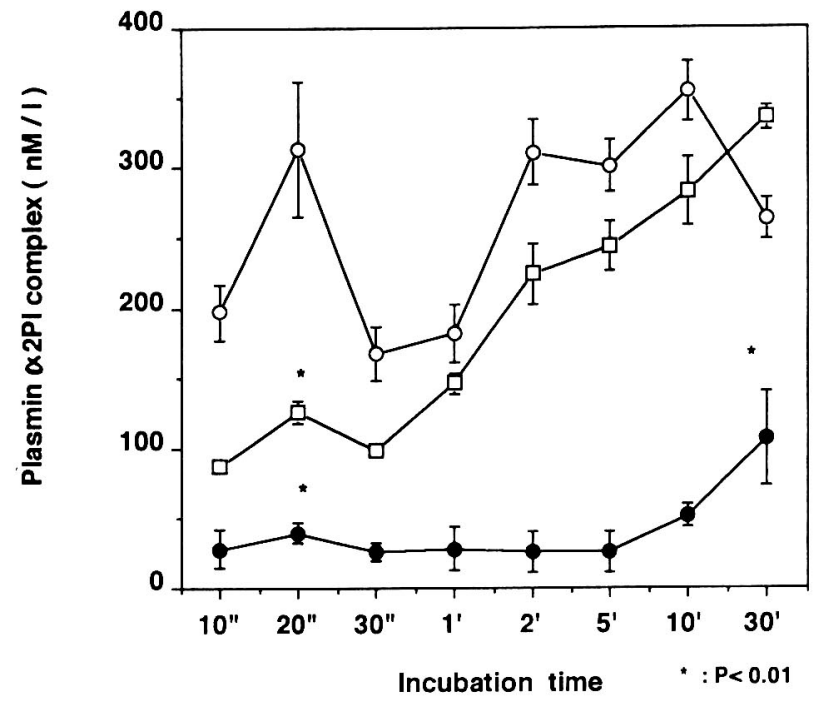

Fig. 3 Time course of the formation of plasmin-glycated $\alpha_{2}$-PI complex. $450 \mu l$ of $\alpha_{2}$-PI was mixed with 100 $\mu l$ of saline or LBS I $(500 \mu \mathrm{g} / \mathrm{m} l)$ and $450 \mu l$ of plasmin $(5 \mathrm{U} / \mathrm{m} l)$ was added and incubated for various times at $37^{\circ} \mathrm{C}$ and the reaction was stopped by $0.2 \mathrm{M}$ DFP. The amounts of complexes were determined.

Control $\alpha_{2}-$ PI+Plasmin : (O), Glycated $\alpha_{2}-\mathrm{PI}+$ Plasmin : (O), Control $\boldsymbol{\alpha}_{2}$-PI+LBS I+Plasmin :

$\mu \mathrm{M} / l$ と著しく増加した（Table 1).

2) 糖化 $\alpha_{2}$-PI とプラスミンの相互反応

(1) SDS-PAGE による分析：糖化 $\alpha_{2}-\mathrm{PI} に$
ウロキナーゼで活性化したプラスミンを作用さ せ, 経時的な変化をSDS-PAGEにて分析した。 実験に用いた $\alpha_{2}-\mathrm{PI}$ および，プラスミンはわれ 

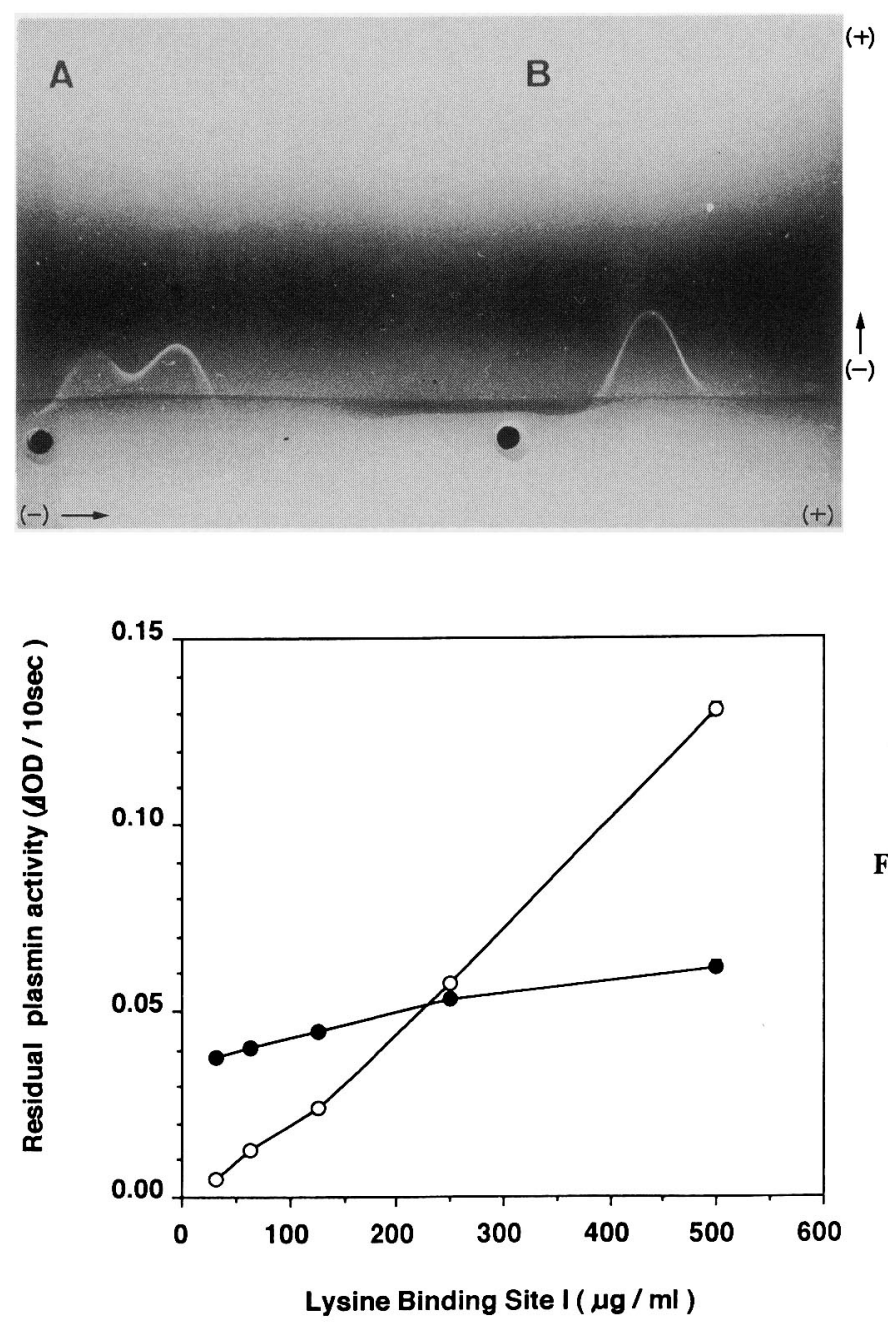

Fig. 4 Crossed immunoelectophoresis of glycated $\alpha_{2}-\mathrm{PI}$ and plas min. Anti human $\alpha_{2}$-PI serum was contained in the second dimension agarose. Control $\alpha_{2}$ PI or glycated $\alpha_{2}-$ PI was in cubated with plasmin and a aliquate of mixture was applied after 10 minutes of incubation and were run 3 hours at $20 \mathrm{~mA}$. A : Control $\alpha_{2}-\mathrm{PI}+\mathrm{Plasmin}, \mathrm{B}$ : Control $\alpha_{2}$-PI+Plasmin

Fig. 5 The effects of LBS I on the interaction of $\alpha_{2}$-PI and Plasmin. $100 \mu l$ of $\alpha_{2}$ - PI $(14.9 \mu \mathrm{M} / l)$ was mixed with $100 \mu l$ of $\mathrm{S}-2251(3 \mathrm{mM})$, and $100 \mu l$ of LBS I $(0 \sim 500 \mu \mathrm{g} / \mathrm{m} l)$ was added, and the mixture was incubated at $37^{\circ} \mathrm{C} .50 \mu \mathrm{l}$ of plasmin ( $5 \mathrm{U} /$ $\mathrm{m} l$ ) was added to the mixture, and the residual plasmin activity was measured. Control $\alpha_{2}$-PI + LBS I+ Plasmin: (O), Glycated $\alpha_{2}-\mathrm{PI}+$ LBS I+Plasmin :

われが用いた泳動条件ではそれぞれ分子量 67 $\mathrm{KD}, 89 \mathrm{KD}$ の位置に単一のバンドとして認め られた（Fig.1レーン 1, 2).コントロールが $\alpha_{2}$ -PI ではプラスミン添加直後 10 秒で既に分子 量 $170 \mathrm{KD}$ の位置に複合体のバンドを確認した (Fig. 1 レーン 3) のに対して糖化 $\alpha_{2}$-PI ではプ ラスミン添加後 30 分まで明らかな複合体形成 が認められなかった（Fig. 2レーン 3〜10).

(2) 複合体形成量の変化： $\alpha_{2}-\mathrm{PI}$ とプラスミ ンの複合体形成量は, コントロール $\alpha_{2}$-PI では プラスミン添加後, ほほ二峰性の複合体形成パ ターンを示し, プラスミン添加直後 10〜20 秒で $313 \mathrm{nM} / l$ の形成量を示した $($ Fig. $3 \bigcirc) . \alpha_{2}-\mathrm{PI}$ とプラスミンの反応系に LBS I $(0.5 \mathrm{mg} / \mathrm{ml})$
を介在させた場合，その複合体形成過程はコン トロールの第一の形成ピークを欠いた形成過程 を示した (Fig. $3 \square)$. 一方，糖化 $\alpha_{2}$-PI では プラスミン添加直後 $10 \sim 20$ 秒で $38 \mathrm{nM} / l$ と著 明な形成低下を認め (Fig. 3 ○) SDS-PAGE の 成績に一致した。

(3) CIE による分析： $\alpha_{2}-\mathrm{PI}$ とプラスミンの 反応を CIEにて分析した.コントロールおよび 糖化 $\alpha_{2}$-PI にプラスミンを作用させて，その CIE 泳動パターンを比較するとコントロール では複合体形成により一峰性である (Fig. 4 B) のに対して糖化 $\alpha_{2}-\mathrm{PI}$ では一元目の陰極側に 複合体を形成しないフリーの $\alpha_{2}$-PI のピーク とコントロールと同じく複合体を形成したピー 
クの二峰性の泳動パターンを示した

(Fig. 4

A).

3) 糖化 $\alpha_{2}$-PI に対する LBS I の影響

糖化 $\alpha_{2}$-PI のプラスミン阻害活性に対する LBS I の影響を検討した。糖化 $\alpha_{2}$-PI と合成 基質の混液に LBS I を添加してプラスミンを 加えた直後 (0.5 秒後) から 10 秒間の吸光度の 変化を比較した.コントロール $\alpha_{2}-\mathrm{PI}$ では LBS I が介在すると $\alpha_{2}-\mathrm{PI}$ のプラスミン阻害活性が 低下して残存プラスミン活性が高くなった (Fig. $5 \bigcirc$ )。しかし, 糖化 $\alpha_{2}$-PI では LBS I の影響を受けず LBS I の濃度に関係なく残存 プラスミン活性は変化が認められなかった (Fig. 5 ○).

\section{考察}

非酵素的な糖化現象は種々の血中タンパク質 がその対象になるものと考えられる。フルクト サミン，へモグロビン $\mathrm{A}_{1 \mathrm{c}}$ のように糖化蛋白を 血糖コントロールの指標に用いる場合 ${ }^{14) 15)}$ は 別として, 臨床的に問題となるのは糖化される ことによるそのタンパク質の機能異常である。 特に高血糖状態を呈する糖尿病などでは大きな 問題になると考えられる.タンパク質の非酵素 的糖化現象はその構成アミノ酸である Lysine 残基のフリーの $\varepsilon$ アミノグループとグルコー スの非酵素的結合 ${ }^{4) 5)}$ による Lysine 残基の変化 に起因する機能障害が問題となる，特に，凝固 線溶系にかかわる種々酵素, 阻害物質において, Lysine 残基は非常に重要なアミノ酸である.わ れわれは以前インビトロにおいて非酵素的に糖 化されたアンチトロンビン III についてそのへ パリン結合部位近傍の Lysine 残基の変化がア ンチトロンビン III の構造変化をもたらしその 複合体形成に障害をもたらす可能性を報告し た ${ }^{3)} \cdot \alpha_{2}$-PI にはプラスミノーゲンの LBS と強 い親和性を有するクリングル結合部位（KBS） にその結合に重要な Lysine 残基が存在 ${ }^{16)}$ する ことから，非酵素的糖化現象による機能障害の 可能性が想像された， $\alpha_{2}$-PI はグルコース 55.5 $\mathrm{mM} / l(1 \mathrm{~g} / \mathrm{d} l)$ の 4 日間のインキュベートで 非酵素的に糖化された。この時, 糖化 $\alpha_{2}$-PI は プラスミン阻害活性が著明に低下した。しかし，
抗原性に変化は認められなかった.SDS-PAGE による分析からコントロール $\alpha_{2}-\mathrm{PI}$ ではブラ スミン添加直後 10 秒で分子量 $170 \mathrm{KD}$ の位置 に複合体のバンドを認めた (Fig.1 レーン 3). このバンドはプラスミノーゲン抗体を用いたウ エスタンブロットによる検討から， $\alpha_{2}-\mathrm{PI}$ とプ ラスミンの複合体であることを確認した（成績 未表示)。一方，糖化 $\alpha_{2}$-PI ではプラスミン添 加後 30 分まで明らかな複合体形成が認められ なかった (Fig. 2 レーン 3〜10)。 $\alpha_{2}$-PI とプラ スミンの複合体形成量はコントロール $\alpha_{2}-\mathrm{PI}$ ではほぼ二峰性の形成過程を示した（Fig. 3 ○). $\alpha_{2}$-PI がプラスミンを阻害する場合，両者 はモル比で 1 対 1 で複合体を形成する ${ }^{6} . \alpha_{2}-\mathrm{PI}$ とプラスミンとの反応は $\alpha_{2}-\mathrm{PI}$ の KBS とプラ スミンの LBS が結合する可逆的な非常に早い 反応と，その後に続く $\alpha_{2}-$ PI の活性部位 (ABS) とプラスミンの活性部位との不可逆的 反応の 2 段階で進行する ${ }^{17) 18)}$. プラスミン, $\alpha_{2}$ PI の反応系にプラスミノーゲンの LBS I を介 在させた場合，コントロール $\alpha_{2}$-PI でみられた 二峰性の複合体形成ピークの最初のピークを欠 いた複合体形成過程を示したことから，この形 成過程の最初のピークは $\alpha_{2}-\mathrm{PI}$ のKBS とプラ スミンの LBS I の反応が大きく関与している と考えられた (Fig. $3 \square)$. 糖化 $\alpha_{2}$-PI の場合 はコントロールの二峰性の形成ピークの最初の ピークは同様に欠いており，第 2 のピークも著 明に低い形成過程を示し，KBS のみならず ABS の変化が示唆された（Fig. 3 O）。二次元 免疫電気泳動による分析ではコントロール $\alpha_{2}-$ PI ではプラスミンとの複合体形成により一次 元目の陽極側に一峰性の沈降線のピークを認め たのに対して糖化 $\alpha_{2}$-PI ではプラスミンと複 合体を形成したピークと陰極側のフリーの $\alpha_{2}-$ PI のピークと 2 つの沈降線のピークを認め, プ ラスミンと複合体を形成しない $\alpha_{2}-\mathrm{PI}$ を認め た (Fig. $4 \mathrm{~A})$.また $\alpha_{2}$-PI のプラスミン阻害反 応における LBS I の影響を調べた成績では, コントロール $\alpha_{2}$-PI では添加する LBSI の量 に依存して残存プラスミン活性が高くなり $\alpha_{2}-$ PI の KBS に対してプラスミンの LBS と添加 した LBS I が競合した。これに対して糖化 $\alpha_{2}$ 
-PI では LBS I の量に関係なく残存プラスミ ン活性はほぼ一定であり糖化 $\alpha_{2}$-PI の KBS の 変化が示唆された。血漿中に存在する $\alpha_{2}$-PI は 二つの異なった分子量を示し，血漿中約 35\%の 低分子量 $\alpha_{2}$-PI はプラスミノーゲンと親和性 を示さない ${ }^{19920)}$ が, 糖化 $\alpha_{2}-\mathrm{PI}$ はプラスミノー ゲンとの親和性の低下のみならず，プラスミン の活性阻害部位の変化も認めた。さらに $\alpha_{2}-\mathrm{PI}$ をグルコースおよび LBS I とインキュベート した場合， $\alpha_{2}$-PI は同様に糖化された（成績末 表示).

これらの成績より非酵素的糖化現象が $\alpha_{2}-\mathrm{PI}$ に及ぼす影響は $\alpha_{2}-\mathrm{PI} の \mathrm{KBS}$ および $\mathrm{ABS}$ 近 傍双方の Lysine 残基にグルコースが結合する ことにより，その機能上の変化を引き起こし， プラスミンとの複合体形成が阻害されることに よりプラスミン阻害活性の低下が起こることが 示唆された。

\section{結語}

1） $\alpha_{2}$-PI はグルコース $(55.5 \mathrm{mM} / l)$ との 4 日間のインキュベートで非酵素的に糖化され， プラスミン阻害活性は著明に低下した。

2) SDS-PAGE による分析から糖化 $\alpha_{2}$-PI はプラスミンと明らかな複合体を形成しなかっ た。

3） $\alpha_{2}$-PI とプラスミンの複合体形成量過程 に二峰性を示し，LBS I を介在させると第一の ピークを欠いた形成過程を示した。糖化 $\alpha_{2}$-PI は両方のピークが著明に低い形成過程を示し た.

4）糖化 $\alpha_{2}$-PI の二次元免疫電気泳動による 分析から,プラスミンと複合体を形成しない $\alpha_{2}$ -PI を認めた。

5） $\alpha_{2}$-PI とプラスミンとの反応系に LBS I を添加した場合，その量に依存して残存プラス ミン活性が高くなったのに対して, 糖化 $\alpha_{2}-\mathrm{PI}$ では LBS I の量に関係なく残存プラスミン活 性はほぼ一定であった。

6）非酵素的糖化現象が $\alpha_{2}-\mathrm{PI} に$ にほすす影響 は $\alpha_{2}$-PI の KBS および ABS 近傍双方にグル コースが結合することによりその機能上の変化 を引き起こしプラスミンとの複合体形成が障害
されることによりプラスミン阻害活性の低下が 起こるものと思われた。

\section{文献}

1) Eble, A.S., Thorpe, S.R. and Baynes, J.W.: Nonenzymatic glucosylation and glucose-dependent cross-linking of proteins. J. Biol.Chem. 258 : 9406 9412, 1983.

2) Brownlee, M., Vlassara, H. and Cerami, A.: Nonenzymatic Glycosylation Reduces the Susceptibility of Fibrin to Degradation by Plasmin. Diabetes $32: 680 \sim 684,1983$.

3）山下 勉, 井上典子, ほか:インビトロにおける非醉 素的糖化現象のアンチトロンビン III におよほすす影 響. 日本血栓止血学会誌 $1: 112 \sim 122,1989$.

4) Brownlee, M. and Cerami, A. : The biochemistry of complications of diabetes mellitus. Ann. Rev. Biochem. 50 : 385 432, 1981.

5) Sensi, M., Pricci, F., Rossi, M.G., Morano, S. and Mario, U.:D-lysine Effectively Decreases the None-Enzymic Glycation of Proteins in Vitro. Clin. Chem. 35 : 384 387, 1989.

6) Moroi, M., and Aoki, N.: Isolation and Characterization of $\alpha_{2}$-Plasmininhibitor from Human Plasma. J. Biol. Chem. 251 : 5956 5965, 1976.

7) Collen, D. : Identification and Some Propeties of New Fast Reacting Plasmin Inhibitor in Human Plasma. J. Bio. Chem. 69 : 209 216, 1976.

8) Aoki, N., Saito, H., Kamiya, T., Koie, K., Sakata, Y. and Kobakura, M.: Congenital deficiency of $\alpha_{2}$-Plasmin inhibitor associated with severe hemorrhagic tendency, J. Clin. Invest., 63 : 877 884, 1977.

9) Naito, K. and Aoki, N.: Assay of $\alpha_{2}$-Plasmin inhibitor activity by means of a plasmin specific tripeptide substrate. Thromb. Res. $12: 1147 \sim$ 1156, 1978.

10) Johnson, R.N. and Baker, J.R.: The Alkaline reducing activity of glycated serum proteins and its relevance to diabetes mellitus. Cin. Chem. 32 : 368 370, 1986.

11) Laemmli, UK.: Cleavege of structural proteins during the assembly of the head of bacteriophage T4. Nature 227 : 680 685, 1970.

12) Sammone, D.W., Adams, L.D. and Nishizawa, E. 
E. : Ultrasensitive silverbased color staining of polypeptide in polyacrylamide gel. Electrophoresis $2: 135 \sim 141,1981$.

13）青木延雄, 武永 強, 長谷川 淳, ほか：EIA 法によ る $\alpha_{2}$-PI (TD-80) および $\alpha_{2}$-PI・プラスミン複合 体（TD-80C）測定キットの基礎的検討. 臨床病理 35 : 111 117, 1987.

14) Johnson, R.N., Metcalf, P.A., Baker, J.R.: Fructosamine : a new approach to the estimation of serum glycosylprotein. An index of diabetic control. Clin. Chim. Acta. 127 : 87 95, 1982.

15) Jovanovic, L., Peterson, C.M.: The clinical utility of glcosylated hemoglobin. Am. J. Med. 70 : 331 338, 1981.

16) Sugiyama, N., Sasaki, T., Iwamoto, M. and Abiko, Y.: Binding site of $\alpha_{2}$-Plasmin inhibitor to plasminogen. Biochem. Biophys. Acta. 952:1 $\sim 7,1988$.

17) Wiman, B. and Collen, D. : On the Kinetics of the Reaction between Human Antiplasmin and Plasmin. Eur. J. Biochem. 84 : 573 578, 1978.

18) Wiman, B., Lijnen H.R. and Collen, D. : ON the specific interaction between the lysine-binding sites in plasmin and complementary sites in $\alpha_{2}$ antiplasmin and in fibrinogen. Biochem. Biophys. Acta. 579 : 142 154, 1979.

19) Christen, U., Clemmesen, I. : Purification and reaction mechanisms of the primary inhibitor of plasma from human plasma. Biochem. J. 175 : 635 〜 641, 1978.

20) Bagge, L., Saldeen, T. : The primary fibrinolysis inhibitor and trauma. Thromb. Res. 13:1131 1136, 1978. 